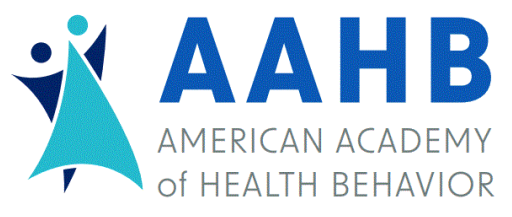

\section{Health Behavior Research}

Volume 1 | Number 1

Article 3

October 2017

\section{The Future of Health Behavior Research}

John B. Lowe

University of the Sunshine Coast, jlowe@usc.edu.au

Follow this and additional works at: https://newprairiepress.org/hbr

Part of the Community Health and Preventive Medicine Commons, and the Public Health Education and Promotion Commons

(c) (i) (9)

This work is licensed under a Creative Commons Attribution-Noncommercial 4.0 License

\section{Recommended Citation}

Lowe, John B. (2017) "The Future of Health Behavior Research," Health Behavior Research: Vol. 1: No. 1. https://doi.org/10.4148/2572-1836.1008

This Commentary is brought to you for free and open access by New Prairie Press. It has been accepted for inclusion in Health Behavior Research by an authorized administrator of New Prairie Press. For more information, please contact cads@k-state.edu. 


\title{
The Future of Health Behavior Research
}

\author{
Abstract \\ This commentary discusses the author's views of the future of health behavior research. \\ Keywords \\ health behavior, research, commentary
}




\section{The Future of Health Behavior Research}

\section{John B. Lowe, MPH, DrPH, FAAHB, FAHPA*}

*Corresponding author can be reached at: jlowe@usc.edu.au

Predicting the future is like predicting the weather. We use a forecast based on certain evidence, but sometimes events happen that few can predict. Having been involved with health behavior research for almost four decades, I have witnessed a lot of changes, and witnessed little change in some areas. Some of the changes have been good, and others have been challenging. We find ourselves in a complex, uncertain, and volatile time in Universities.

The biggest change has been the total number of talented researchers that are involved in behavioral research, specifically intervention research and translational research. The scores for National Institutes of Health (NIH), and my country's own National Health and Medical Research Council (NHMRC), continue to be more competitive with more applications each year. Good research has not always been funded but as the numbers of applications increase, greater numbers of fundable research studies will go unfunded. Randomized control trials (RCT) continue to be the style of research funded. Innovative research that is not an RCT will always find it a challenge to get funded, but we should never give up on innovative work in place of the same old, same old research.

Research that includes the biopsychosocial and the environment will continued to be highly desired. ${ }^{1}$ The biggest move I see is for the evaluation of outcomes to be more biological based, more biological measure as was used in smoking cessation research, but on a population basis. Measures, such as the Body Mass Index to measure changes in obesity, will not be the standard, but will need to be established from low-cost genetic markers.

One of the emerging areas in health behavior research will be in epigenetics. While it did not rank highly in the Delphi, that will change in the next few years. The key question that needs to be answered is: Do environmental aspects, including individual behaviors, override the genetics for certain behaviors, or does the genetic makeup of an individual at birth predetermine everything? Can we change the expression of our genes based on our behavior? The interaction of health behavior and genetics will certainly become more predominant in our literature.

Scholars from disciplines other than our usual partners will be our new coinvestigators. Historians, philosophers, and artists will collaborate with us on our projects. While the behavioral sciences will always have psychology, sociology, and anthropology as the bases, other areas such as transportation, economics, and town planning will have more of a prominence and profile in our research.

From my crystal ball, the reporting of heath behavior research is changing and will continue to change. Online journals have become mainstream and will continue to take over as paper journals will become a thing of the past. The need to get your paper cited will be a measure of your quality and not quantity. SciVal and $\mathrm{H}$ indexes have put new meaning to publish or perish. Universities' rankings on the world stage depend on it. An academic's worth will be measured by matrices, more than any other indicator. The American Academy of Health Behavior may need to alter the use of the quantity of publications to a measure of quality, as the two are often similar, but they can differ.

Publishing of journals is a big business. The smaller publishing houses will continue to fold, or be bought out by the bigger publishing houses. Never in history has it been so expensive to conduct good research and to publish your research in a highly cited indexed journal. Academics now need money to publish, which is likely to bias against particular 
research that does not lend itself to funding. Universities may provide such funding, but it would be influenced by the priorities of the deans of the faculties. The grey literature, including social media, will be increasingly used to get information to the readers. This could in turn change the outcomes of systematic reviews, and influence the direction of science. Our current system of peer review is not sustainable because universities continue not to reward academics for their participating in this system.

In summary, I hope that I have made a few points for your consideration. Only time will be able to tell us what was the future.

\section{References}

1. McBride CM, Bryan AD, Bray MS, et al. Health behavior change: can genomics improve behavioral adherence? Am J Public Health. 2012;102(3):401-405.

https://doi.org/10.2105/ajph.2011.300513. 